\title{
Urban Sprawl Typology in Semarang City
}

\author{
Yutri Aprillia *, Bitta Pigawati
}

University of Diponegoro, Jl. Prof. Soedarto, Tembalang, Kota Semarang, Jawa Tengah 50275, Indonesia

1)yutriaprillia@gmail.com, ${ }^{2)}$ bitta.pigawati@gmail.com

\begin{abstract}
The population and economic growth increase the need of space leading to an increase in built-up area. There is an increased activity in the city centre which results in the residents feeling less comfortable to live in the area. Hence, the growth of the settlement area tends to head towards the periphery. This condition is an indication of the developments of the built-up area in the periphery. Urban sprawl is a phenomenon of development of an irregular built-up area which leads to the suburbs. Urban development as a result of urban sprawl will trigger an increase in the demand for supporting facilities and infrastructure. An urban Sprawl in Semarang City has resulted in the establishment of residential areas in a conserved region, which is against zoning regulations in the Semarang City Spatial Planning Document (RTRW). Urban Sprawl Typology Research in Semarang City aims to analyse the urban sprawl typology in the city. By knowing the typology, it can minimise the impact of urban sprawl. This research was conducted using the remote sensing method and geographic information system (GIS) with the Shannon's Entropy approach. The results indicated that in 2006 and 2016, urban sprawl in Semarang City had three types of typology that can be classified as typology I (low level), typology II (medium level) and typology III (high level). The impact of urban sprawl on typology II and III can be minimised through the provision of affordable housing with adequate infrastructure, and an improvement in the permit system for housing and settlement development.
\end{abstract}

Keywords: urban sprawl, Shannon's entropy, GIS, remote sensing, Semarang.

\begin{abstract}
Abstrak. Pertambahan jumlah penduduk dan pertumbuhan ekonomi berimplikasi pada kebutuhan ruang untuk beraktivitas sehingga menyebabkan terjadinya peningkatan built up area. Peningkatan aktivitas pusat kota yang tinggi menyebabkan penduduk kurang nyaman untuk tinggal di kawasan pusat kota. Sehingga terjadi pertumbuhan kawasan permukiman menuju ke arah pinggiran. Kondisi ini merupakan salah satu indikasi perkembangan built up area di kawasan pinggiran. Urban sprawl merupakan fenomena perkembangan built up area yang tidak teratur mengarah ke pinggiran kota. Perkembangan kota sebagai dampak urban sprawl akan meningkatkan permintaan terhadap sarana dan prasarana pendukung. Penelitian Tipologi Urban Sprawl di Kota Semarang bertujuan untuk menganalisis tipologi urban sprawl di Kota Semarang, dengan diketahui tipologi maka dapat dilakukan upaya untuk meminimalisasi dampak urban sprawl. Penelitian ini dilakukan menggunakan metode remote sensing dan geographic information system (GIS) dengan pendekatan Shannon's Entropy. Hasil penelitian menunjukkan bahwa pada tahun 2006 dan tahun 2016, urban sprawl di Kota Semarang memiliki 3 jenis tipologi yang dapat dibedakan menjadi tipologi I (tingkat rendah), tipologi II (tingkat sedang) dan tipologi III (tingkat tinggi). Dampak urban sprawl pada tipologi II dan III dapat diminimalisasi dengan penyediaan perumahan terjangkau dengan sarana prasarana yang memadai dan perbaikan sistem perijinan pembangunan perumahan dan permukiman.
\end{abstract}

Kata kunci: urban sprawl, Shannon's entropy, GIS, Semarang.

\section{Introduction}

Urban sprawl is a contemporary issue of world cities (Suditu et al., 2010). This phenomenon emerges as a development of scattered pattern of low-density townships that is isolated from the city centre to the 
periphery of the suburbs and can result in environmental degradation (Bhatta et al., 2010; Ewing et al., 2002; Hasse \& Lathrop, 2003; Tian et al., 2017; Yeh \& Li, 2001). Although this phenomenon is massively discussed, yet there has been no consistent indicator to measure, define and evaluate the impact of this process (Yeh \& Li, 2001). Unclear definitions and characteristics make sprawl measurement analysis a challenging task (Bhatta et al., 2010; Wilson et al., 2003).

The development of cities, in relation with the phase of suburbanisation, can potentially initiate urban sprawl. There are four phases of urbanisation: urbanisation, suburbanisation, dis-urbanisation and reurbanisation (Antrop, 2004). Urbanisation is one of the most important socio-economic issues in contemporary society. It can be attributed to rapid population (Rukmana \& Rudiarto, 2016) and economic growth (Wu and Zhang, 2012). These growths become irreversible factors in the transformation of land use from rural areas into urban dominant areas (Buchori et al., 2017; Schneider \& Woodcock, 2008). The higher the economic growth of a country or region, the higher its level of urbanisation. This rapid economic growth will provide a trickle-down effect on urban fringed areas (Yunus, 1999). The term "urbanisation" refers to an increase in the built-up area due to increased human activities, and it is influenced by economic, social and geographical factors of a region (Bharath et al., 2017; Sudhira \& Ramachandra, 2007; Jaya, 2009).

Suburbanisation is characterised by the growth of built-up areas on the periphery. Urban centres focus more on economic (commercial) activities. Therefore, settlements will grow in the suburbs (suburban) (Antrop, 2004; Handayani \& Rudiarto, 2014). The spilling over of settlement areas and excessive use of open landscape, especially the low dense settlements in urban fringed areas will result in conditions known as urban sprawl (Pozoukidou \& Ntriankos, 2017).

Semarang as the capital of Central Java province is one of the metropolitan cities in Indonesia, with a population of 1.73 million as at 2017, and an increase of nearly 350,000 in 2006 (Semarang Central Bureau of Statistics, 2017). It is also the centre of the National Strategic Area of Kedungsepur (Kendal, Demak, Ungaran, Salatiga, Semarang and Purwodadi). It is estimated that one-third of the Kedungsepur population lives in Semarang City. The builtup area of the city consequently grew up by 961.17 ha between 2006 and 2012 (Nahib, 2016). The residents preferring suburban areas is attributable to the higher activities in the urban areas. This has been established with the rate of negative population growth of $5 \%-21 \%$ in the city centre area.

In contrast, the urban fringed area experienced a population growth rate above $30 \%$ since 2006 . Semarang city has a built-up area due to the development of industrial areas in the north and that of housing in the south and east. The development of Semarang City to urban suburb shows the existence of urban sprawl symptoms (Hadi, 2013).

The development of such a dispersed built-up area tends to require more facilities and infrastructure on a large scale (Solé-Ollé et al., 2010). Moreover, the residential section of the built-up area in Semarang City is developed in the conservation area. Consequently, this development disobey the government regulation of the Semarang City Spatial Planning Document (RTRW) (Pigawati et al., 2017). Such phenomenon indicates that there is inadequate control of land development planning (Inostroza et al., 2013). Urban sprawl will increase the demand for supporting facilities and infrastructure that lead to complex problems. Therefore, studies to analyse the urban sprawl phenomenon is important. This research aimed at analysing urban sprawl typology in Semarang City, so efforts can be made to minimise the impact of urban sprawl.

\section{Research Method}

This research used the quantitative descriptive method, where the data which was extracted from remote sensing imageries was analysed quantitatively with a spatial approach, by overlay analysis technique, of Geographic Information System (GIS). 


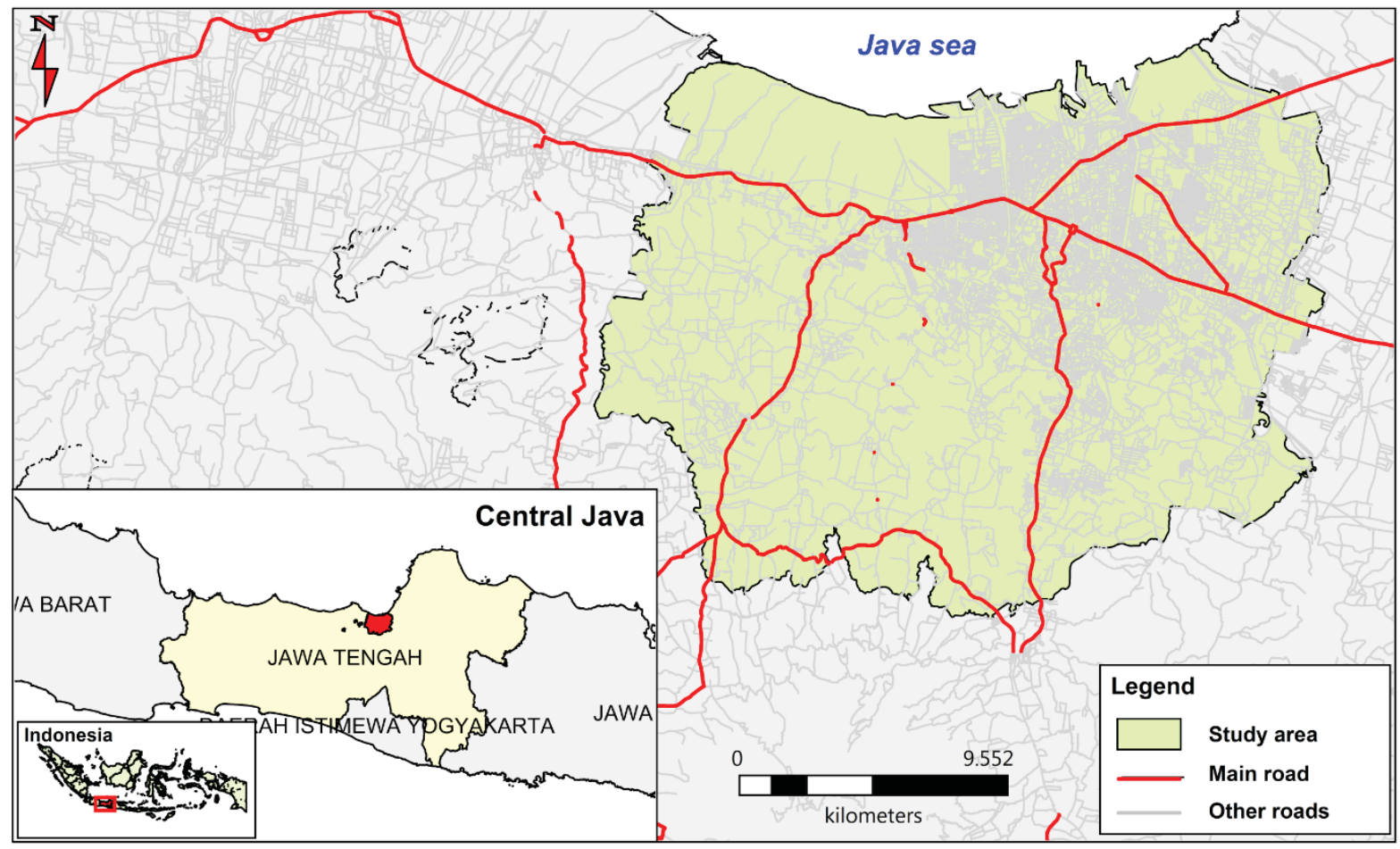

Figure 1. Research location.

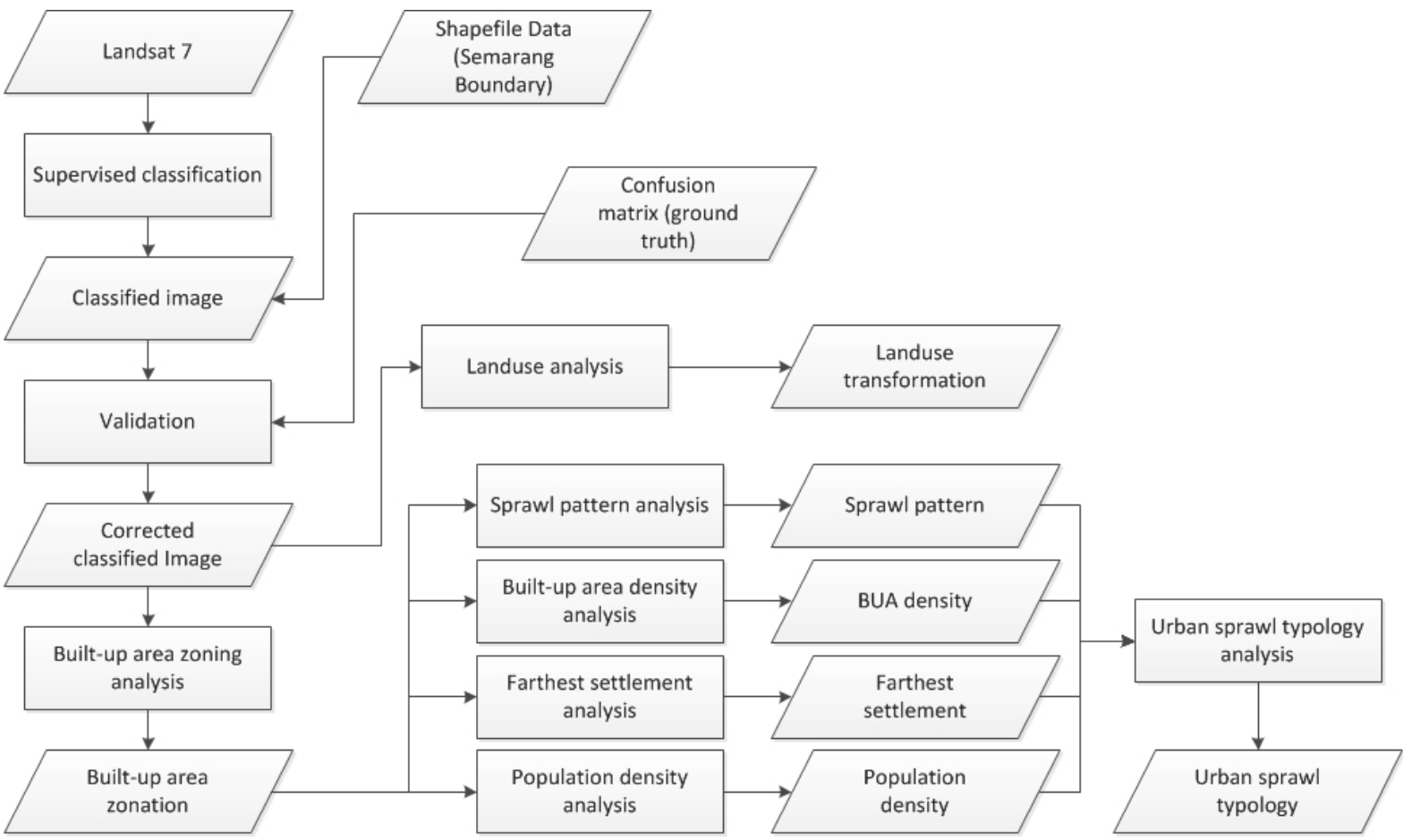

Figure 2. Flowchart for urban sprawl typology analysis.

\subsection{Study Area}

The research was conducted in Semarang City (Figure 1). This city is located in Central Java Province, Indonesia, and it administratively comprises of 16 districts with an area of $382,241 \mathrm{~km}^{2}$. Administratively, the study area is adjacent to Kendal regency in the west, Semarang regency in the south, Demak regency in the east and the Java Sea in the north. 
Table 1. Landuse transformation of built-up area and non-built-up area in $2006-2016$

\begin{tabular}{|c|c|c|c|c|c|c|c|c|}
\hline \multirow[t]{2}{*}{ No. } & \multirow[t]{2}{*}{ District } & \multicolumn{2}{|c|}{$\begin{array}{l}\text { Built up area } \\
\qquad\left(\mathrm{km}^{2}\right)\end{array}$} & \multicolumn{2}{|c|}{$\begin{array}{c}\text { Non Built up area } \\
\left(\mathrm{km}^{2}\right)\end{array}$} & \multicolumn{2}{|c|}{$\begin{array}{c}\text { Growth of Built Up } \\
\text { Area }\end{array}$} & \multirow[t]{2}{*}{$\begin{array}{l}\text { Total } \\
\left(\mathrm{km}^{2}\right)\end{array}$} \\
\hline & & 2006 & 2016 & 2006 & 2016 & Area $\left(\mathrm{km}^{2}\right)$ & $\%$ & \\
\hline 1 & Mijen & 1.936 & 6.202 & 51.904 & 47.638 & 4.27 & $9.93 \%$ & 53.84 \\
\hline 2 & Gunungpati & 2.352 & 5.648 & 59.14 & 55.844 & 3.335 & $7.76 \%$ & 61.492 \\
\hline 3 & Banyumanik & 8.148 & 12.706 & 22.778 & 18.22 & 4.565 & $10.62 \%$ & 30.926 \\
\hline 4 & Gajah Mungkur & 4.733 & 5.324 & 4.681 & 4.09 & 0.592 & $1.38 \%$ & 9.414 \\
\hline 5 & Semarang Selatan & 4.757 & 5.006 & 1.389 & 1.14 & 0.251 & $0.58 \%$ & 6.146 \\
\hline 6 & Candisari & 4.333 & 4.884 & 2.28 & 1.729 & 0.501 & $1.17 \%$ & 6.613 \\
\hline 7 & Tembalang & 10.632 & 18.459 & 30.82 & 22.993 & 7.834 & $18.23 \%$ & 41.452 \\
\hline 8 & Pedurungan & 10.44 & 14.805 & 11.546 & 7.181 & 4.375 & $10.18 \%$ & 21.986 \\
\hline 9 & Genuk & 6.372 & 11.759 & 20.925 & 15.538 & 5.612 & $13.06 \%$ & 27.297 \\
\hline 10 & Gayamsari & 3.47 & 4.226 & 2.965 & 2.209 & 0.76 & $1.77 \%$ & 6.435 \\
\hline 11 & Semarang Timur & 3.833 & 4.176 & 1.784 & 1.441 & 0.347 & $0.81 \%$ & 5.617 \\
\hline 12 & Semarang Utara & 5.846 & 6.711 & 5.558 & 4.693 & 0.878 & $2.04 \%$ & 11.404 \\
\hline 13 & $\begin{array}{l}\text { Semarang Ten- } \\
\text { gah }\end{array}$ & 4.181 & 4.404 & 1.173 & 0.95 & 0.227 & $0.53 \%$ & 5.354 \\
\hline 14 & Semarang Barat & 11.313 & 13.348 & 10.838 & 8.803 & 2.068 & $4.82 \%$ & 22.151 \\
\hline 15 & Tugu & 2.636 & 4.621 & 27.563 & 25.578 & 2.03 & $4.70 \%$ & 30.199 \\
\hline \multirow[t]{2}{*}{16} & Ngaliyan & 9.304 & 14.56 & 35.611 & 30.355 & 5.336 & $12.42 \%$ & 44.915 \\
\hline & Total & 94.286 & 136.839 & 290.955 & 248.402 & 42.981 & $100.00 \%$ & 385.241 \\
\hline
\end{tabular}

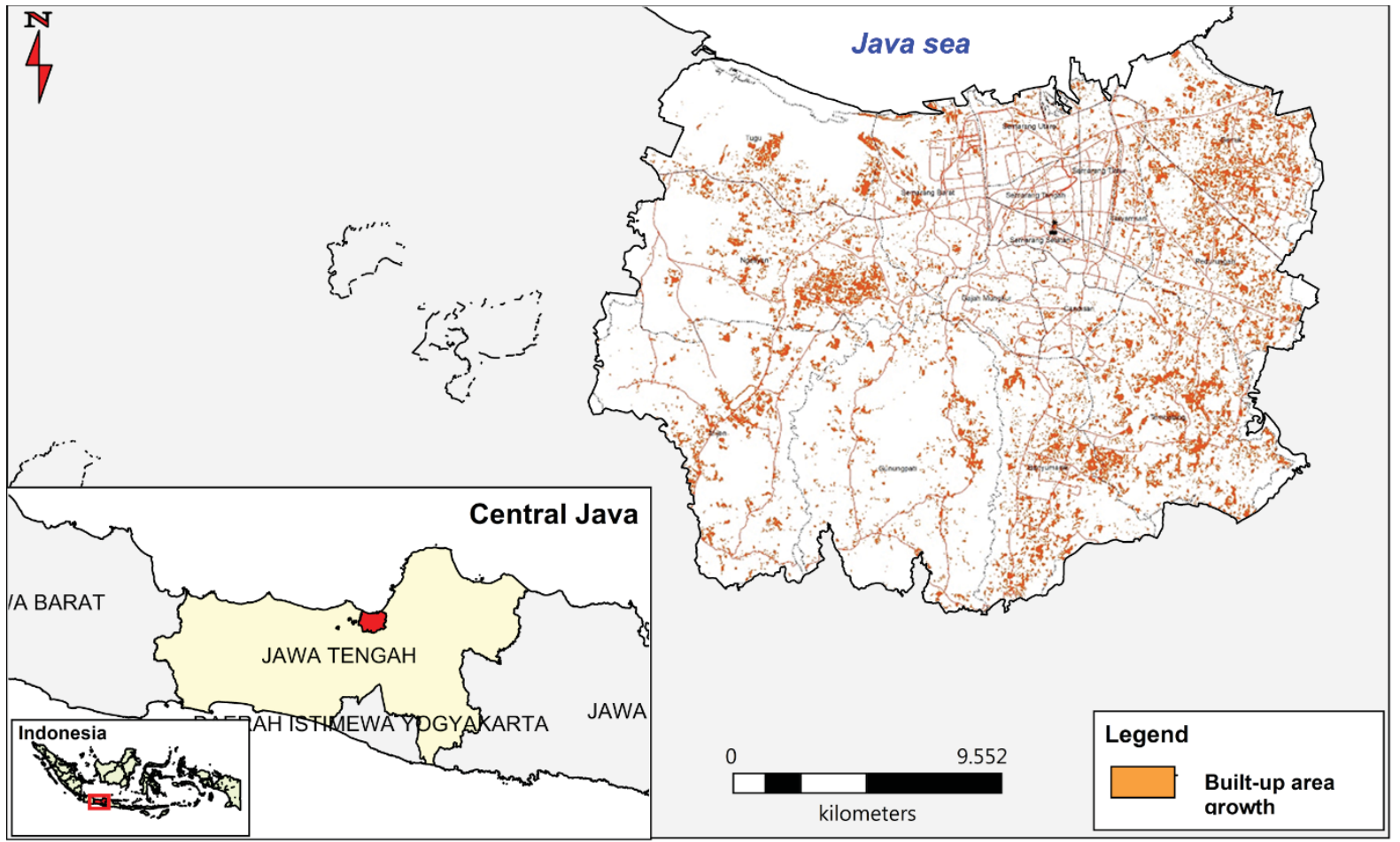

Figure 3. Built-up area growth. 
Table 2. Built Up Area Zoning in Semarang.

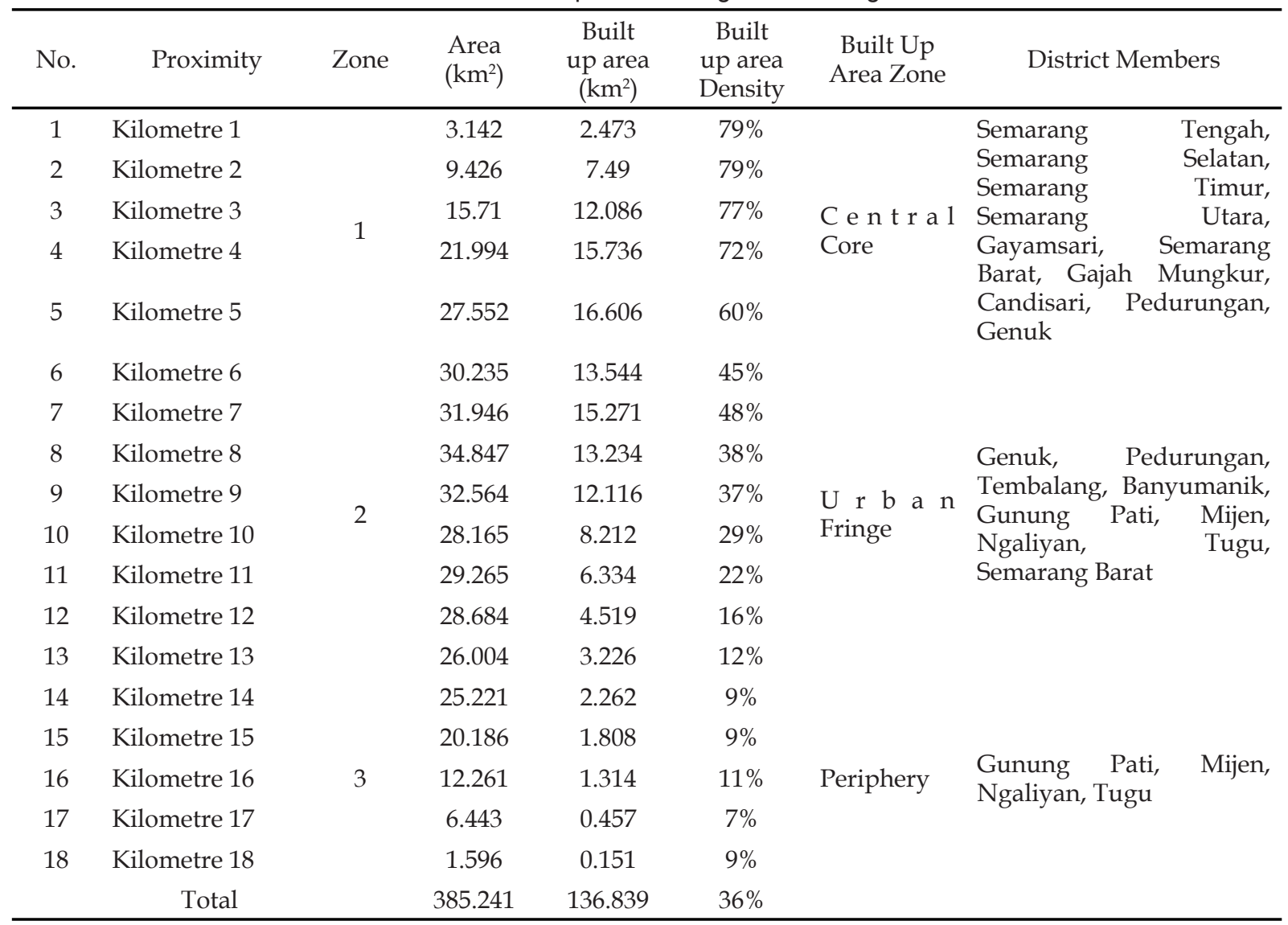

\subsection{Datasets}

Datasets used on this paper is Landsat TM 7 image retrieval period August 2016 and June 2006 with $30 \mathrm{~m}$ resolution. The ten years gap was used because it represents the urban built area growth. The classification result has an accuracy matrix of $92 \%$ and $88 \%$. These results indicate that the accuracy (limitation) requirements have been met and, therefore, ready for further analysis (Summer \& Nordman, 2008).

\subsection{Urban Sprawl analysis}

Theanalysis of sprawllocation determination in Semarang City was carried out to discover the sprawl zone (Figure 2). The sprawl location was determined by using Shannon's Entropy Index, considering two aspects of the city centre (CBD) and the main road network in the city. Shannon's entropy (Equation 1) can be employed in measuring the dispersion or compactness of a variable $(x)$ in zones (n). Where $\mathrm{H}_{0}$ is Shannon's entropy, while $\mathrm{Pi}$ is the possibility of a phenomenon (variable) that occurs in the i-zone. The value of pi is determined by Equation 2. $\mathrm{Xi}$ is the observed value of the variables within the $\mathrm{i}$-zone, while $\mathrm{n}$ is the total zone. $\mathrm{Xi}$ in this study is the density of built-up land in each zone, whereas $\mathrm{X} 1$ is the total density of built-up land.

$H_{0}=\sum_{i}^{n} p_{i} \log \left(\frac{1}{p_{1}}\right)$

$p_{i}=x_{i} / \sum_{i}^{n} x_{1}$

A city has a built-up land distribution concentrated next to the road if the value of the entropy index is close to 0 , and if it is close to 1 then it indicates that the city is spreading away from the road and is referred to as urban sprawl (Bhatta et al., 2010; Prasetyo et al., 2016; Shekhar, 2004; Verma et al., 2017; Yeh and Li, 2001). The value of the entropy index $(\mathrm{Hn})$ is scaled from 0 to $\log \mathrm{n}$. There is a relative entropy index $\left(\mathrm{Hn}^{\prime}\right)$ to facilitate the reading of the entropy index value that scales the entropy index from 0 to 1. 


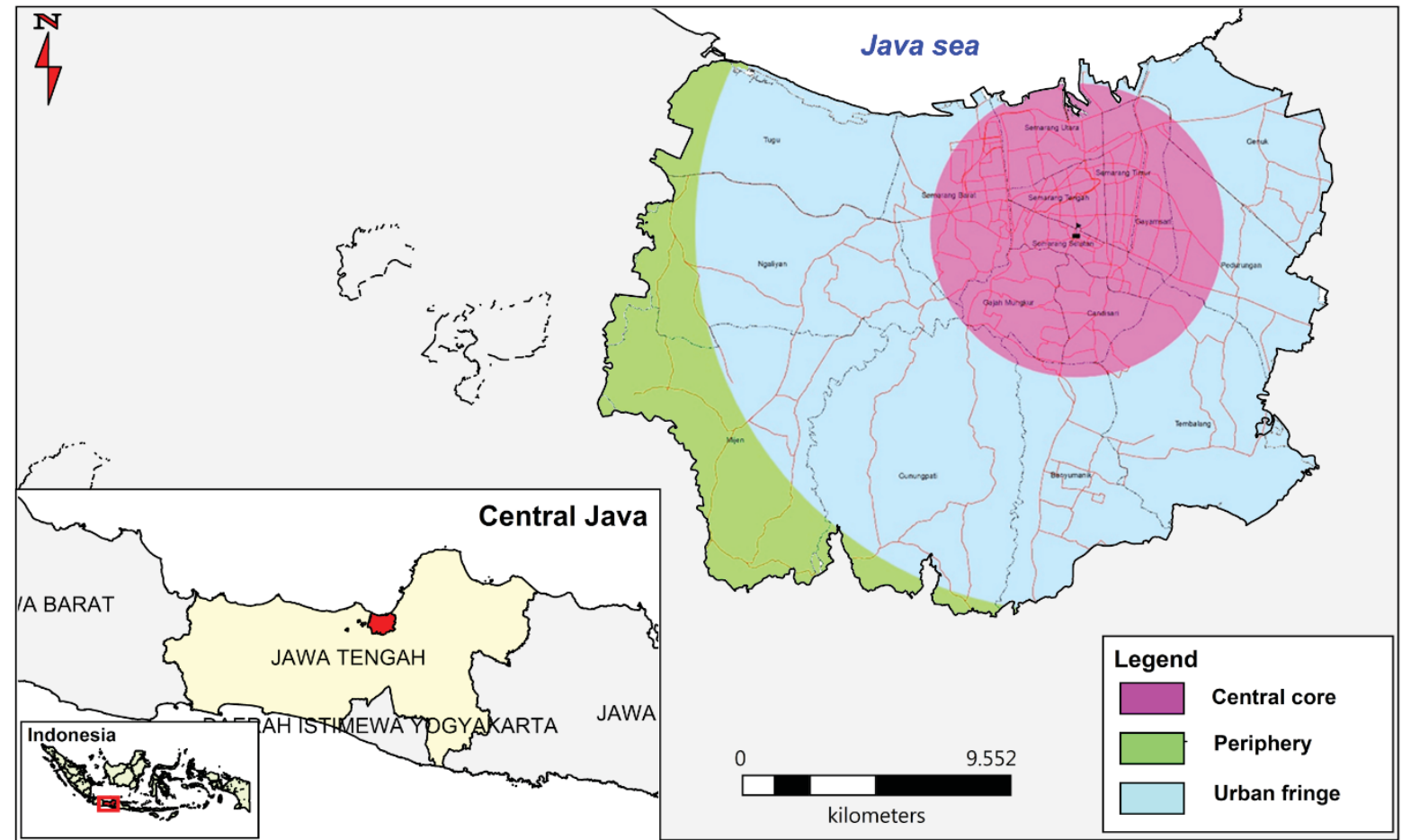

Figure 4. Urban land zoning.

Table 3. Urban sprawl in 2006 and 2016.

\begin{tabular}{|c|c|c|c|c|c|c|c|}
\hline \multirow[t]{2}{*}{ No. } & \multirow[t]{2}{*}{ Zone } & \multicolumn{2}{|c|}{$\begin{array}{l}\text { Town Centre Relative } \\
\text { Entropy Index }\left(\mathrm{HnT}^{\prime}\right)\end{array}$} & \multirow[t]{2}{*}{$\mathrm{T}^{\prime}$} & \multicolumn{2}{|c|}{$\begin{array}{l}\text { Main Road Relative } \\
\text { Entropy Index (HnR') }\end{array}$} & \\
\hline & & $2006(\mathrm{t} 1)$ & 2016 (t2) & & $2006(\mathrm{t} 1)$ & $2016(\mathrm{t} 2)$ & \\
\hline 1. & Central Core & 0.71 & 0.76 & 0.05 & 0.98 & 0.99 & 0.01 \\
\hline 2. & Urban Fringe & 0.68 & 0.96 & 0.28 & 0.96 & 0.98 & 0.02 \\
\hline 3. & Periphery & 0.59 & 0.99 & 0.4 & 0.79 & 0.89 & 0.1 \\
\hline 4. & Semarang & 0.70 & 0.91 & 0.21 & 0.94 & 0.97 & 0.03 \\
\hline
\end{tabular}

$\mathrm{HnT}^{\prime}=$ = Town Centre Relative Entropy Index , HnR' = Main Road Relative Entropy Index, = Town Centre Relative Entropy Index change, = Main Road Relative Entropy Index change

\subsection{Typology Classification}

\subsubsection{The Sprawl Pattern Analysis}

The sprawl pattern analysis was carried out to establish the patterns of urban disperse, by making the relative entropy space matrix using the relative entropy index value. The entropy space matrix relative will form 4 quadrants, each of which will represent one sprawl pattern, i.e. dispersed medium development (concentric), dispersed high development, concentrated low development (ribbon development), highly dispersed - high development (leapfrog).

\subsubsection{Built-up Area Density Analysis}

Built-up area density analysis was conducted to calculate the changes of the density from 2006 to 2016. The analysis of the built-up area density in Semarang was developed by multiple ring buffer method, using Simpang Lima as the centre of Semarang City. The multiple ring buffer produced urban zones with intervals $1 \mathrm{~km}$ started from the centre. The built-up area density analysis was conducted on each zone separately.

\subsubsection{Farthest Settlement Analysis}

Farthest settlement analysis or central business district (CBD) was conducted to determine the distance of the farthest settlement of each zone from the city centre. This analysis was carried out by calculating the distance of the farthest urban settlement in Semarang City to its CBD (Simpang Lima). The analysis was 
performed by using network analysis extension in ArcGIS 10.3 software.

\subsubsection{Population Density Analysis}

The population density analysis was conducted to identify the population density changing between 2006 and 2016. It was conducted in Semarang City by making population density point on kelurahan unit and created multiple ring buffer method using the reference of Simpang Lima as the centre of Semarang City. Further identification of population density was performed at intervals of $1 \mathrm{~km}$ away from the city centre.

\subsubsection{Urban Sprawl Typology Analysis}

The urban sprawl typology analysis was conducted based on the result of sprawl characteristic analysis to form typology. Scoring analysis was used in dividing sprawl typology into three sprawl classes, i.e. high, low and medium. Sprawl level is lower when the variable value of the sprawl pattern, build-up land density and population density are low, while it is higher when the variable distance to city centre is high.

\section{Results and Discussion}

\subsection{Landuse}

Semarang City has a total area of 385,241 $\mathrm{km}^{2}$ comprising of settlements, industries, water bodies, vegetation and bare land which are classified into two types namely: builtup and non-built-up areas. Table I shows the changes of built-up and non-built-up lands from 2006 to 2016. Whereas Tembalang is the sub-district with the highest built-up area change (18.23\%). Pigawati \& Rudiarto (2011) found similar result on their study. However, in this study, we found that Semarang Tengah Sub-district is the lowest built-up area change $(0.53 \%)$. The unique phenomena occur in Semarang City, and sub-districts located in urban fringe (Genuk, Ngaliyan, Banyumanik, Pedurungan, Mijen, Gunungpati and Tugu) have more built-up area changes compared to sub-districts located in the city centre area (Semarang Utara, Gayamsari, Gajahmungkur, Candisari, Semarang Timur, Semarang Selatan, Semarang Tengah). This corresponds with the study by Dadi et al. (2016) which stated that fringes are built-up area growth changes linked to urban sprawl phenomenon, urban sprawl drove ALC (Agricultural Land Conversion) i.e. agricultural land change to built-up area (Dadi et al., 2016). The spatial distribution of land use change in Semarang City is provided in Figure 3.

\subsection{Built-Up Area Zoning}

Built-up area zoning in Semarang City was carried out to divide Semarang City into zones based on built-up land density. There are three zones were defined based on this approach namely central core, fringe and periphery zones. Urban land delineation was conducted using modified zone analysis by Schneider \& Woodcock (2008) and Shekhar (2004) to locate physically identifiable urban zones based on built-up land density and distance to urban centres.

The results of the zoning are provided both in tabular (Table 2) and spatial (Figure 4). Based on the results of urban land zoning (Table 2), there are ten sub-districts included in the central core namely Semarang Tengah, Semarang Selatan, Semarang Timur, Semarang Utara, Gayamsari, Semarang Barat, Gajah Mungkur, Candisari, Pedurungan and the northern and eastern parts of Genuk District. Urban fringe has nine sub-districts including Genuk, Pedurungan, Tembalang, Banyumanik, Gunung Pati, Mijen, Ngaliyan, Tugu and Semarang Timur. While the periphery zones has three sub-districts, and they are the southern part of Gunung Pati, most of the eastern Mijen, east part of Ngaliyan and Tugu. An illustration of the spatial distribution of urban land zoning analysis in Semarang City can be seen in Figure 4. 
Table 4. Sprawl patterns in 2006 - 2016.

\begin{tabular}{|c|c|c|c|c|c|c|c|}
\hline \multirow[t]{2}{*}{ No. } & \multirow[t]{2}{*}{ Zone } & \multicolumn{2}{|c|}{$\begin{array}{l}\text { Town Centre Relative } \\
\text { Entropy Index }\left(\mathrm{HnT}^{\prime}\right)\end{array}$} & \multicolumn{2}{|c|}{$\begin{array}{l}\text { Main Road Relative } \\
\text { Entropy Index (HnR') }\end{array}$} & \multirow[t]{2}{*}{ 2006's Pattern } & \multirow[t]{2}{*}{ 2016's Pattern } \\
\hline & & $2006(t 1)$ & $2016(\mathrm{t} 2)$ & $2006(t 1)$ & $2016(\mathrm{t} 2)$ & & \\
\hline 1 & Central Core & 0.71 & 0.76 & 0.98 & 0.99 & $\begin{array}{l}\text { highly } \\
\text { dispersed high } \\
\text { development }\end{array}$ & $\begin{array}{l}\text { highly } \\
\text { dispersed high } \\
\text { development }\end{array}$ \\
\hline 2 & $\begin{array}{l}\text { Urban } \\
\text { Fringe }\end{array}$ & 0.68 & 0.96 & 0.96 & 0.98 & $\begin{array}{l}\text { highly } \\
\text { dispersed high } \\
\text { development }\end{array}$ & $\begin{array}{l}\text { highly } \\
\text { dispersed high } \\
\text { development }\end{array}$ \\
\hline 3 & Periphery & 0.59 & 0.99 & 0.79 & 0.89 & $\begin{array}{l}\text { dispersed } \\
\text { medium } \\
\text { development }\end{array}$ & $\begin{array}{l}\text { highly } \\
\text { dispersed high } \\
\text { development }\end{array}$ \\
\hline 4 & Semarang & 0.7 & 0.91 & 0.94 & 0.97 & $\begin{array}{l}\text { highly } \\
\text { dispersed high } \\
\text { development }\end{array}$ & $\begin{array}{l}\text { highly } \\
\text { dispersed high } \\
\text { development }\end{array}$ \\
\hline
\end{tabular}

HnT' = Town Centre Relative Entropy Index , HnR' = Main Road Relative Entropy Index

Table 5. Built up area density.

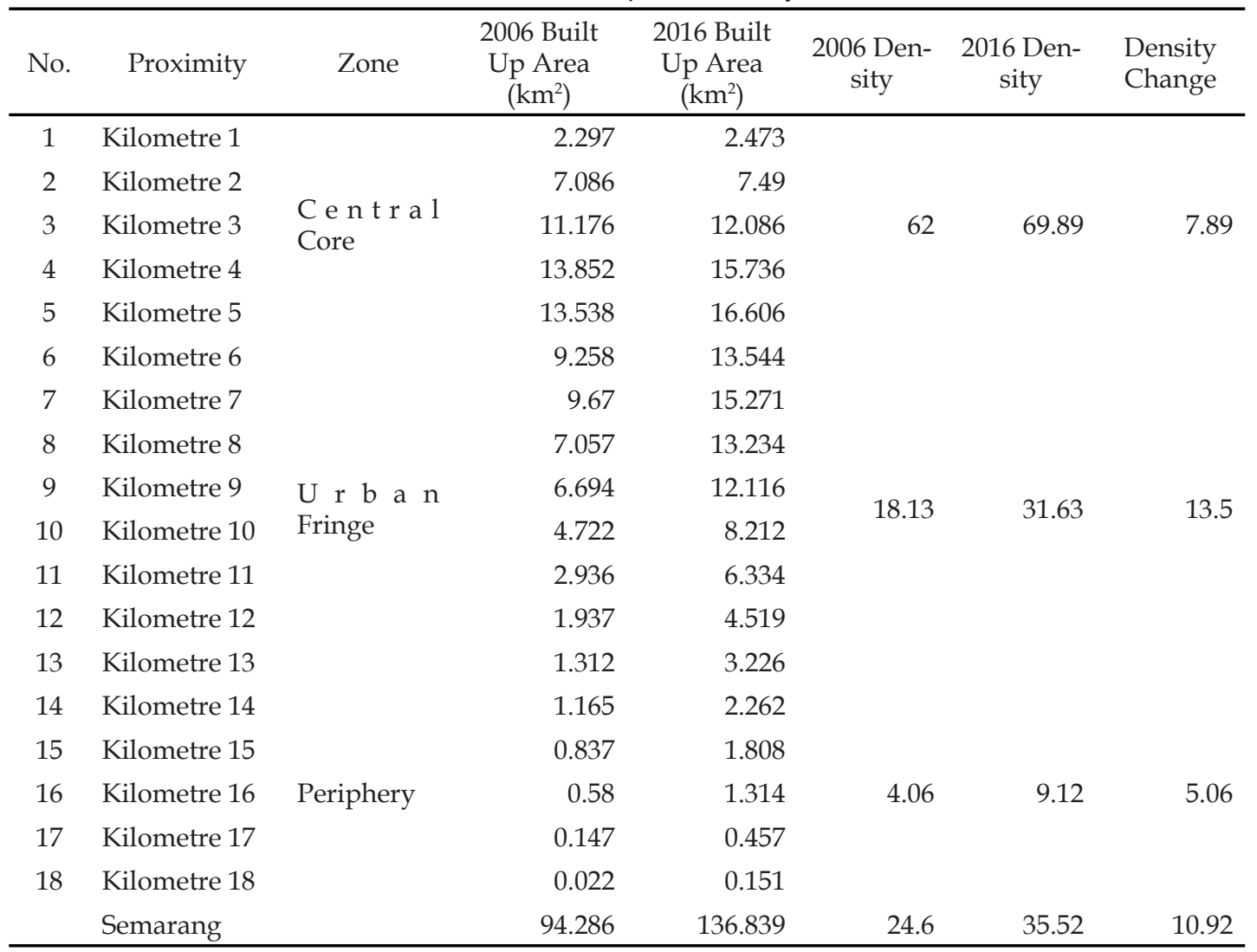

\subsection{Urban Sprawl}

The results of urban sprawl analysis are presented in Table 3. This table shows that, based on the city centre of 2006 and 2016, the urban sprawls occurred in each zone because they have a Relative Entropy Index close to the maximum value (1). This indicates that each zone (Figure 4) is dispersed and growing farther from the main road. Sprawl based on city centre in 2006, the central core has the highest Relative Entropy Index (0.71), whereas periphery has a Relative Entropy Index with the lowest value (0.59). In contrast, in 2016, periphery had the largest Relative Entropy Index (0.99), while the central core has a Relative Entropy Index with the lowest value (0.76). In 2006 and 2016, sprawl 
based on the main road, the central core has the highest Relative Entropy Indexes (0.98 and 0.99 respectively) while the periphery has the lowest Relative Entropy Indexes (0.79 and 0.89 respectively). Based on the changes in Relative Entropy Index value, periphery has the highest change values at 0.4 and 0.1 . This suggests that urban sprawl in periphery evolves towards becoming more dispersed (sprawl). This is in accordance with a previously conducted research by Hadi (2013) which stated that the development of Semarang city to the urban fringe indicates the existence of urban sprawl symptoms.

\subsection{Urban Sprawl Pattern}

Sprawl pattern analysis is conducted in order to establish the sprawl pattern of each zone (Figure 4). This analysis was performed using Relative Entropy Index value towards the city centre $\left(\mathrm{HnT}^{\prime}\right)$ and on the road $\left(\mathrm{HnR}^{\prime}\right)$. The result of Sprawl pattern analysis can be seen in Table 4 . This table shows that in 2006, the sprawl pattern is highly dispersed - high development or referred as a leapfrog development. While in 2016, the sprawl pattern is highly dispersed high-growth (leapfrog). In detail, this sprawl pattern occurs at all zones in 2006 except the periphery that has a dispersed medium development (concentric) sprawl pattern. The development of this pattern was close to the city centre and has a small Relative Entropy Index value. In contrast, in 2016, leapfrog sprawl pattern applies to all zones. This indicates that the periphery experienced a more severe sprawl pattern over ten years.

\subsection{Built Up Area Density}

Built-up area density analysis is carried out in order to calculate the density change of the built-up area between 2006 and 2016. The results of the land density analysis are presented in Table 5. This table shows that in 2006, the central core has the highest built-up area density (62\%), urban fringe has an established land density of $18.13 \%$, and the periphery has the lowest density (4.06\%). However in 2016, the central core has the largest built-up density (69.89\%), urban fringe has a built-up area density of $31.63 \%$, and periphery has the lowest density $(9.12 \%)$. The zone with the highest land density growth is the urban fringe (13.5\%), followed by the central core $(7.89 \%)$, and then the periphery $(5.06 \%)$. Urban fringe is the only zone that has experienced an infilling trend. Infilling trends in urban fringe are associated with increased residential development in this zone, due to withdrawal factors in the form of education areas (Tembalang subdistrict, Genuk sub-district and Gunungpati sub-district) and industrial areas (Genuk subdistrict, Tugu sub-district, Ngaliyan district and Pedurungan sub-district).

Built-up area density trend from the centre to the suburb of the city can be established by connecting the density of a built-up area at a distance to the city centre. Built-up area density trend (Figure 5) has drastically decreases in the two-kilometre area from the city centre and then rises on 6 to 7 kilometres and 17 to 18 kilometres. This is due to the development of the city on the suburb of Semarang/suburbanises as stated by Handayani \& Rudiarto (2014), infringe and periphery precisely.

\subsection{Farthest Settlement Proximity}

The proximity of the farthest settlement analysis is conducted to determine the distance of the farthest settlements in each zone from the city centre. This analysis is performed by calculating the distance of the farthest settlement in kelurahan, Semarang City to Semarang City CBD (Simpang Lima). The analysis was carried out using network analysis extension in ArcGIS 10.3 software. A scoring analysis was then conducted to classify the Proximity of the farthest settlement into three classes: high, low and medium. The proximity of the farthest settlement analysis can be seen in Figure 6. 


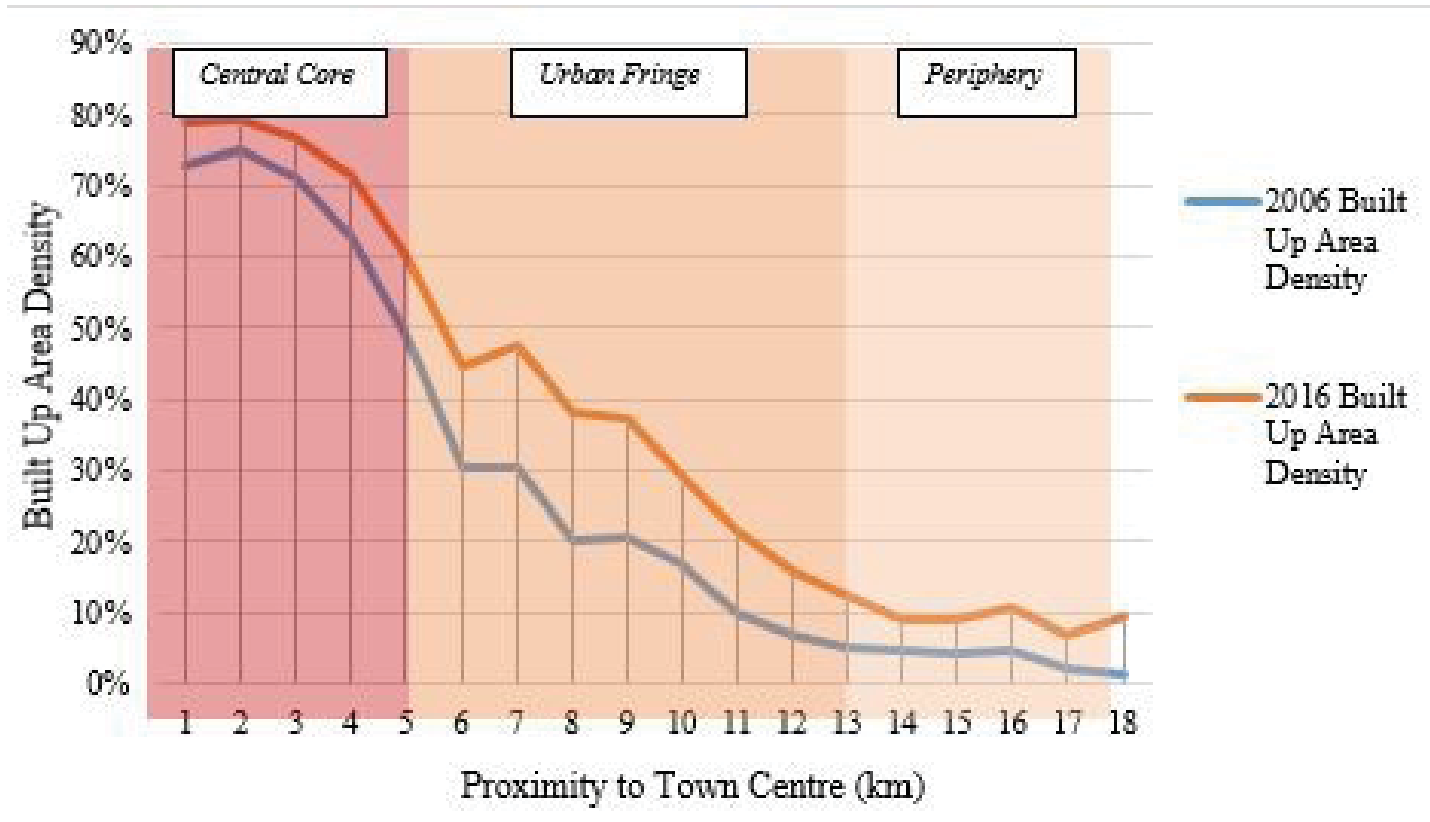

Figure 5. Built-up area density trend in 2006 - 2016.

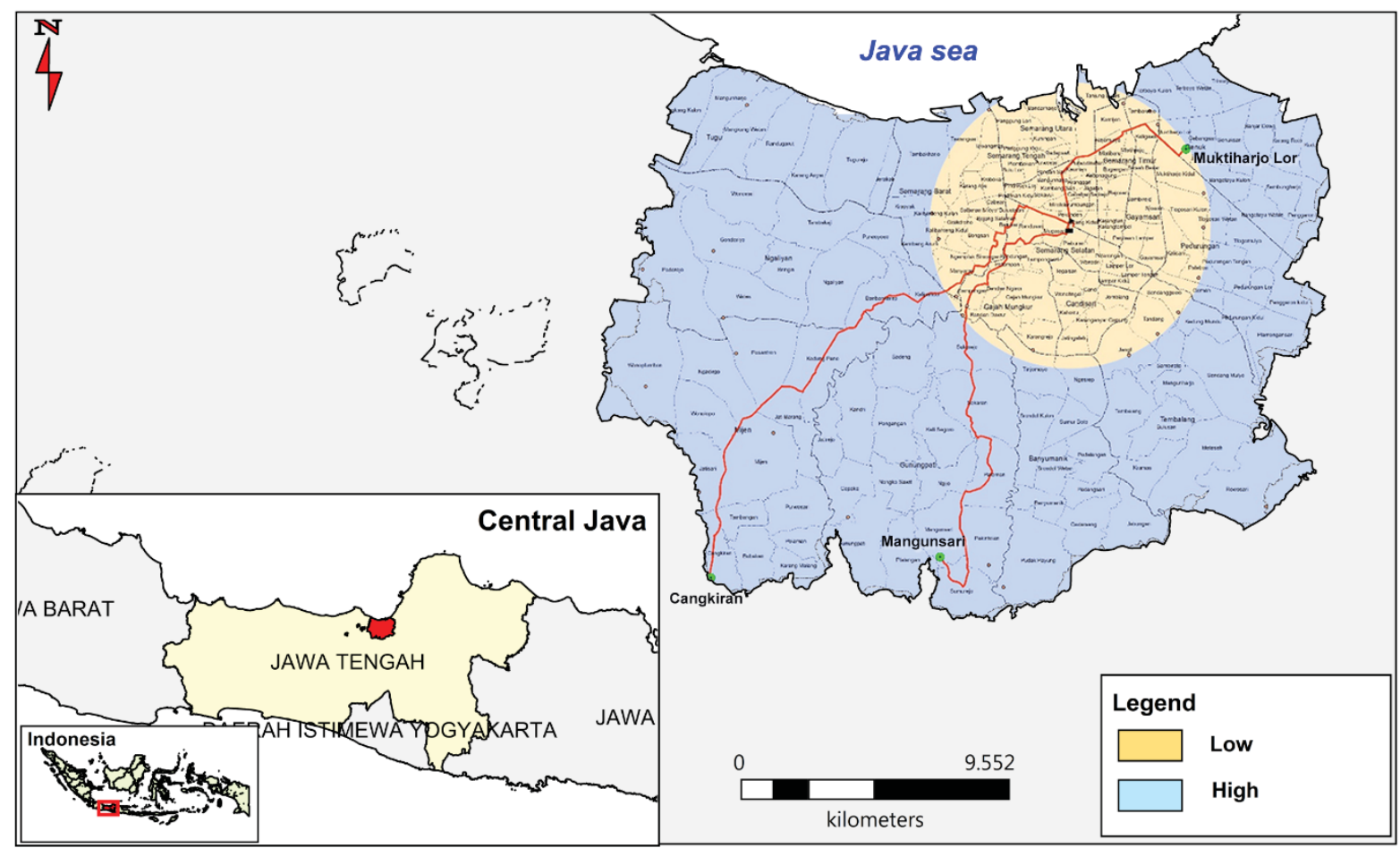

Figure 6. Proximity of the furthest settlement.

The settlement with the farthest distance on the periphery is the one at Kelurahan Cangkiran, with a distance of $22,935 \mathrm{~m}$, and a travel time of 27 minutes. In urban fringe, the farthest settlement from the city centre is the one at Kelurahan Mangunsari which is with a distance of $18,887 \mathrm{~m}$ and a travel time of 21 minutes. In central core, the farthest settlement is located in Kelurahan Muktiharjo Lor with $7,456 \mathrm{~m}$ and the fastest travel time is 9 minutes. The results of the scoring analysis show that central cores enter into a high level, while urban fringe and periphery enter into a low level. 
Table 6. Population density change in $2006-2017$.

\begin{tabular}{|c|c|c|c|c|c|c|c|}
\hline No. & Zone & Proximity & $\begin{array}{l}2006 \text { Popu- } \\
\text { lation Den- } \\
\text { sity (Inhabi- } \\
\text { tants } / \mathrm{km}^{2} \text { ) }\end{array}$ & $\begin{array}{c}2016 \text { Popula- } \\
\text { tion Density } \\
\text { (Inhabitants } \\
\quad / \mathrm{km}^{2} \text { ) }\end{array}$ & $\begin{array}{c}2006 \text { Popula- } \\
\text { tion Density } \\
\text { (Inhabitants / } \\
\mathrm{km}^{2} \text { ) }\end{array}$ & $\begin{array}{c}2016 \text { Popula- } \\
\text { tion Density } \\
\text { (Inhabitants / } \\
\mathrm{km}^{2} \text { ) }\end{array}$ & $\begin{array}{l}\text { Population } \\
\text { Density } \\
\text { Change (In- } \\
\text { habitants / } \\
\mathrm{km}^{2} \text { ) }\end{array}$ \\
\hline 1 & \multirow{5}{*}{$\begin{array}{l}\text { Central } \\
\text { Core }\end{array}$} & Kilometre 1 & 10762 & 10166 & \multirow{6}{*}{12660} & \multirow{5}{*}{12279} & \multirow{5}{*}{-382} \\
\hline 2 & & Kilometre 2 & 15146 & 13969 & & & \\
\hline 3 & & Kilometre 3 & 16754 & 15925 & & & \\
\hline 4 & & Kilometre 4 & 12210 & 12235 & & & \\
\hline 5 & & Kilometre 5 & 8430 & 9097 & & & \\
\hline 6 & \multirow{8}{*}{$\begin{array}{l}\text { Urban } \\
\text { Fringe }\end{array}$} & Kilometre 6 & 4747 & 5466 & & \multirow{8}{*}{2975} & \multirow{8}{*}{528} \\
\hline 7 & & Kilometre 7 & 3220 & 3779 & \multirow{7}{*}{2447} & & \\
\hline 8 & & Kilometre 8 & 2323 & 2930 & & & \\
\hline 9 & & Kilometre 9 & 3335 & 3909 & & & \\
\hline 10 & & Kilometre 10 & 2602 & 2943 & & & \\
\hline 11 & & Kilometre 11 & 1396 & 2013 & & & \\
\hline 12 & & Kilometre 12 & 1181 & 1614 & & & \\
\hline 13 & & Kilometre 13 & 770 & 1142 & & & \\
\hline 14 & \multirow{4}{*}{ Periphery } & Kilometre 14 & 996 & 1200 & \multirow{4}{*}{1100} & \multirow{4}{*}{1427} & \multirow{4}{*}{327} \\
\hline 15 & & Kilometre 15 & 1003 & 1277 & & & \\
\hline 16 & & Kilometre 16 & 1493 & 2041 & & & \\
\hline 17 & & Kilometre 17 & 909 & 1190 & & & \\
\hline
\end{tabular}

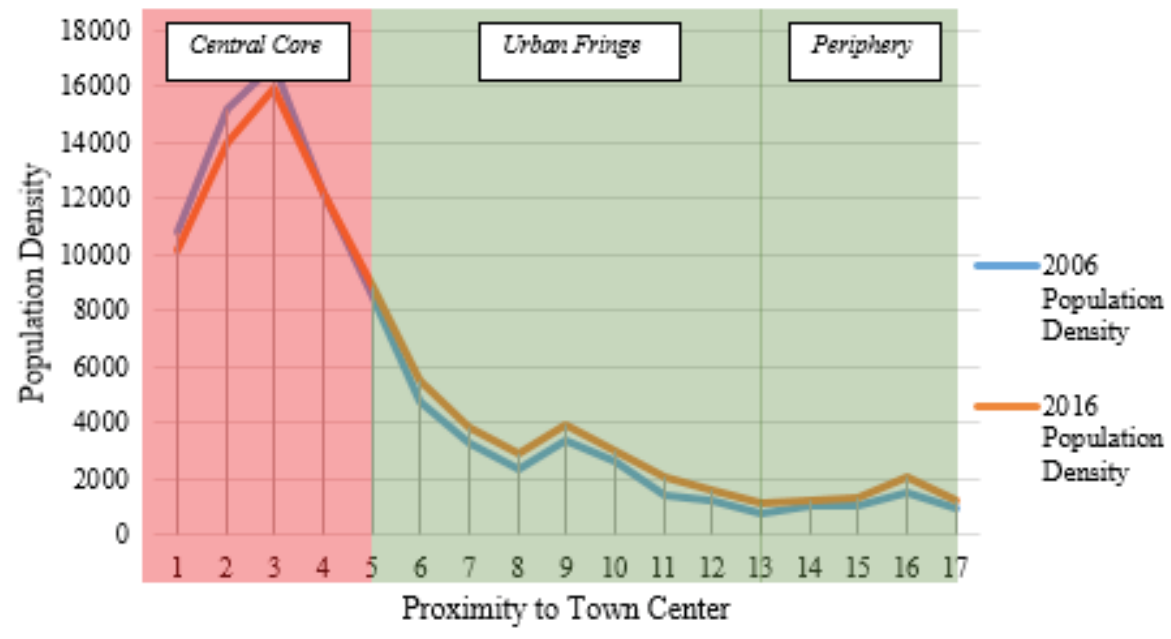

Figure 7. Population density trend in 2006- 2016.

\subsection{Population Density}

Population density analysis was conducted to identify the population density change in 2006 and 2016. The results of the population density analysis can be seen in Table 6 while the trend is provided in Figure 7. The table shows that in 2006, central cores has the highest population density $\left(12,660\right.$ inhabitants $\left./ \mathrm{km}^{2}\right)$, urban fringe has a density of 2,447 inhabitants/ $\mathrm{km}^{2}$, and periphery has the lowest population density (1100 inhabitants $\left./ \mathrm{km}^{2}\right)$. While in 2016, the central core has the highest population density $(12,279 / \mathrm{km} 2)$, the urban fringe has a density of 2,975 inhabitants $/ \mathrm{km}^{2}$, and the periphery has the lowest population density (1427 inhabitants $/ \mathrm{km}^{2}$ ). The zone with the highest population density change is the urban fringe (528 inhabitants $/ \mathrm{km}^{2}$ ), followed by the periphery (327 inhabitants $/ \mathrm{km}^{2}$ ), and then the central core with a negative population density change (-382 inhabitants $\left./ \mathrm{km}^{2}\right)$. This shows the dynamics of the population, the declining 
density of the central core population and the increasing population density in the periphery of Semarang City (urban fringe and periphery). Based on the scoring analysis, central core enters the high level, while urban fringe and periphery enter the low level.

Based on Figure 7, there is a trend of decreasing the population density in the city centre and increasing in urban fringe and periphery, which is consistent with the research from Handayani \& Rudiarto (2014). The decline in central cores signifies a reduction in the population living in the city centre. The figure also shows that there is different growth of population density in urban fringe and periphery due to an increase in population density. People preferred to live in the suburbs as a result of the attraction of education areas (Tembalang subdistrict, Genuk subdistrict and Gunungpati subdistrict) and industrial areas (Genuk subdistrict, Tugu subdistrict, Ngaliyan subdistrict and Pedurungan subdistrict).

\subsection{Urban Sprawl Typology}

Urban sprawl typology analysis was performed based on the analysis of sprawl characteristics. Scoring analysis was used in dividing sprawl typology into three sprawl classes, i.e. high, low and medium sprawl typology. The results of this analysis were expected to reveal a more explicit phenomenon of urban sprawl that occurred in the Semarang city (Table 7). Sprawl level will be lower if sprawl pattern, the density of the built-up area and population density are low and vice versa.
It also gets higher when the distance to the city centre has high value.

There are variability of typological dynamics of the zones (Figure 8). From 2006 to 2016, central cores did not experience any typological change or the characteristics are remain steady, but the built-up area has increased. During this decade, urban fringe changed from typology III (2006) to typology II (2016), and characteristics of built-up area density progressed from low level (2006) to medium (2016). The increase in built-up area density and population density causes this zone to progress to a moderate sprawl. The increase in the built-up area and the population density occurred as a result of a pull which is due to the education and industrial areas in the urban fringe. Tembalang sub-district (Diponegoro University), Gunung Pati subdistrict (Semarang State University) and Genuk sub-district (Sultan Agung Islamic University) are centres of higher education in Semarang, while Genuk (Merdeka Wirastama), Tugu (Wijaya Kusuma) Pedurungan and Ngaliyan sub-districts (Candi Industry) are the centres of industrial and warehousing area in Semarang City. Periphery underwent a typology transformation from typology II (2006) to typology III (2016). The change characteristic is the sprawl pattern, and this zone has dispersed medium development sprawl pattern (2006) into highly dispersed high development (leapfrog) sprawl pattern in 2016. The changing of sprawl pattern make this zone increase in sprawl level (typology II to typology III).

Table 7. Urban Sprawl Typology Score in Semarang 2006 - 2016.

\begin{tabular}{|c|c|c|c|c|c|c|c|c|c|c|c|c|c|}
\hline \multirow[t]{2}{*}{ No. } & \multirow[t]{2}{*}{ Zone } & \multicolumn{2}{|c|}{$\begin{array}{l}\text { Sprawl } \\
\text { Pattern }\end{array}$} & \multicolumn{2}{|c|}{$\begin{array}{c}\text { Built } \\
\text { up area } \\
\text { Density }\end{array}$} & \multicolumn{2}{|c|}{$\begin{array}{l}\text { The } \\
\text { proximity of } \\
\text { The Furthest } \\
\text { Settlement }\end{array}$} & \multicolumn{2}{|c|}{$\begin{array}{c}\text { Population } \\
\text { Density }\end{array}$} & \multicolumn{2}{|c|}{ Total Score } & \multicolumn{2}{|c|}{ Typology } \\
\hline & & 2006 & 2016 & 2006 & 2016 & 2006 & 2016 & 2006 & 2016 & 2006 & 2016 & 2006 & 2016 \\
\hline 1 & $\begin{array}{l}\text { Central } \\
\text { core }\end{array}$ & 4 & 4 & 1 & 1 & 1 & 1 & 1 & 1 & 7 & 7 & $\begin{array}{c}\text { Typology } \\
\text { I }\end{array}$ & $\begin{array}{c}\text { Typology } \\
\text { I }\end{array}$ \\
\hline 2 & $\begin{array}{l}\text { Urban } \\
\text { fringe }\end{array}$ & 4 & 4 & 3 & 2 & 3 & 3 & 3 & 3 & 13 & 12 & $\begin{array}{c}\text { Typology } \\
\text { III }\end{array}$ & $\begin{array}{c}\text { Typology } \\
\text { II }\end{array}$ \\
\hline 3 & Periphery & 1 & 4 & 3 & 3 & 3 & 3 & 3 & 3 & 10 & 13 & $\begin{array}{c}\text { Typology } \\
\text { II }\end{array}$ & $\begin{array}{c}\text { Typology } \\
\text { III }\end{array}$ \\
\hline 4 & Semarang & 4 & 4 & 3 & 2 & 3 & 3 & 2 & 2 & 12 & 11 & $\begin{array}{c}\text { Typology } \\
\text { II }\end{array}$ & $\begin{array}{c}\text { Typology } \\
\text { II }\end{array}$ \\
\hline
\end{tabular}




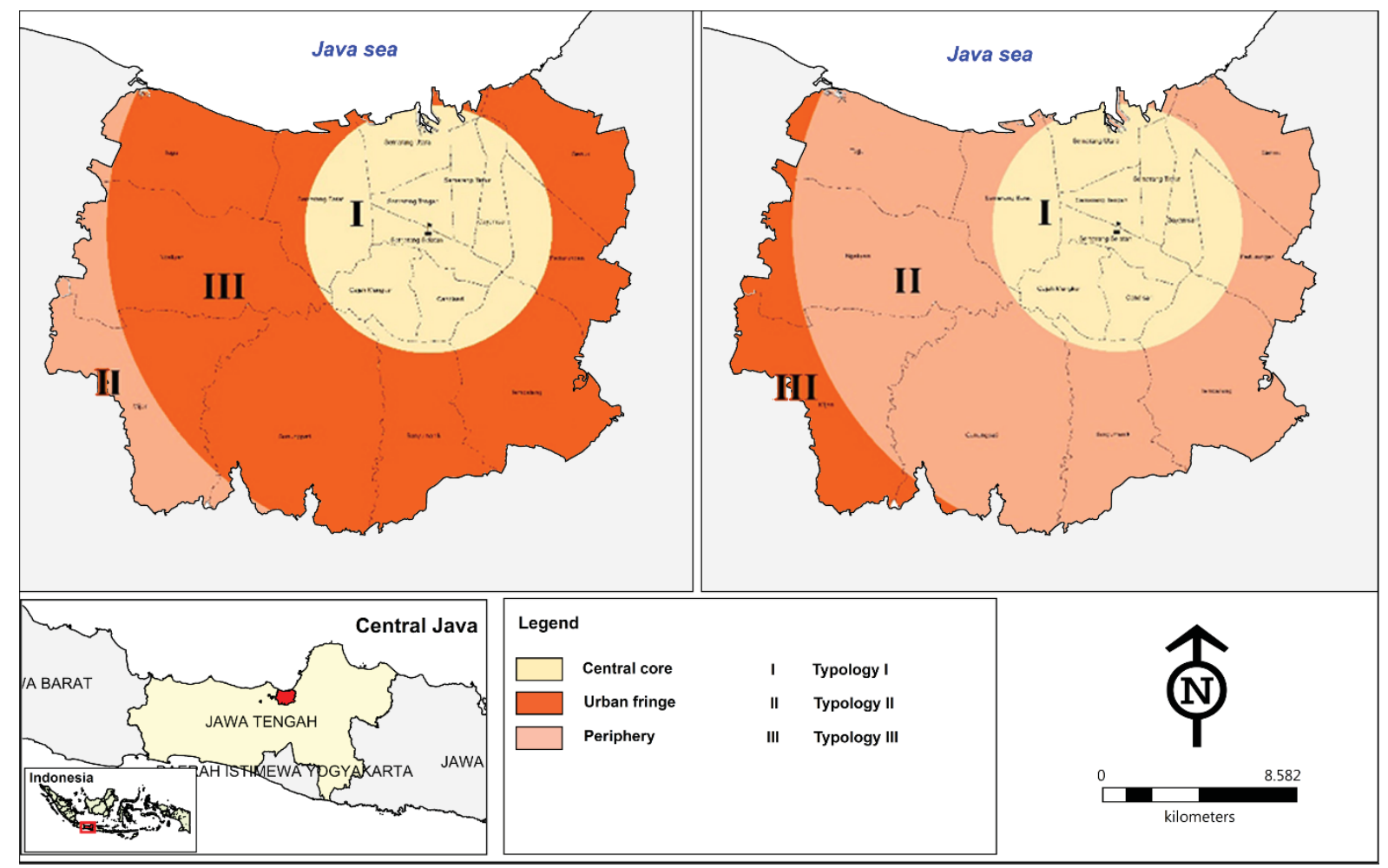

Figure 8. Urban Sprawl typology zoning in 2006 (left) and 2016 (right).

\subsection{Discussion}

The results indicate that there are three types of urban sprawl typologies in Semarang City including typology I (low level), typology II (medium level) and typology III (high level). From 2006 to 2016, urban fringe and periphery are experienced with sprawl level changes, as urban fringe progressed from typology III to typology II due to an infilling trend. The periphery zone, on the other hand, has increased sprawl level (typology II to typology III), and this shows that the development of settlements in periphery has a high level of sprawl phenomenon. Urban development as a result of urban sprawl will increase the demand for supporting facilities and infrastructure, especially in zones that have sprawl typology II and III. The impact of urban sprawl on zones with typology II and III can be minimised with the provision of affordable housing with adequate infrastructure and an improvement in the permit system for housing and settlement development.

This is in line with previously conducted studies by Prasetyo et al. (2016); Shekhar
(2004) and Yeh \& Li, (2001) that Shannon's entropy with GIS integration is the best method for measuring urban sprawls in developing countries. A research by Hadi (2013) on urban Sprawl in Semarang stated that the development of Semarang city to the urban fringe signifies the existence of an urban sprawl. The same result was also reported by Handayani \& Rudiarto (2014) that there is a sub-urbanisation process that indicates urban sprawl in Semarang Metropolitan City. In addition, study by Bhatta et al. (2010) stated that the most widely used characteristics for describing and measuring sprawls are a builtup area (population) and proximity from the town centre.

\section{Conclusion}

Semarang city experienced the growth of the built-up area as an impact of the suburbanisation process. This phenomenon can be identified from the change of non-built up area into built-up area. The city centre as the centre of commercial activities caused the development of the city to shift towards fringe 
with low density and fragmented (sprawl). Shannon's entropy with GIS integration is an effective method for measuring urban sprawl, as it illustrates the level of built-up area widespread in an area. This study shows that in 2006 and 2016, urban sprawl in Semarang City had three types of typology that can be classified as typology I (low level), typology II (medium level) and typology III (high level). The impact of urban sprawl on typology II and III can be minimised through the provision of affordable housing with adequate infrastructure, and an improvement in the permit system for housing and settlement development.

\section{Acknowledgements}

We would like to express sincere gratitude to Wiwandari Handayani who has guided to ensure that this research was properly conducted. Our big thanks also go to Prita Ramadiani, Nisa Iksi Rosa and Januarta D. Kusmayanti who provided insight and expertise that greatly assisted the research.

\section{References}

Antrop, M. (2004). Landscape Change and the Urbanization Process in Europe. 67: 9-26.

Bharath, H.A., M.C. Chandan, S. Vinay, and T.V. Ramachandra. (2017). Modelling Urban Dynamics in Rapidly Urbanising Indian Cities. The Egyptian Journal of Remote Sensing and Space Science.

Bhatta, B., S. Saraswati, and D. Bandyopadhyay. (2010). Urban Sprawl Measurement from Remote Sensing Data. Applied Geography 30(4): 731-40. http://dx.doi.org/10.1016/j. apgeog.2010.02.002.

Buchori, I, Sugiri, A., Maryono, M., Pramitasari, A., Pamungkas, I.T.D. (2017). Theorizing Spatial Dynamics of Metropolitan Regions: A Preliminary Study in Java and Madura Islands, Indonesia. Sustainable Cities and Society 35: 468-82.

Dadi, D. Azadi, H., Senbeta, F., Abebe, K., Taheri, F., Stellmacher, T. (2016). Urban Sprawl and Its Impacts on Land Use Change in Central Ethiopia. Urban Forestry \& Urban Greening 16: 132-41.

Ewing, R., Pendall, R., Chen, D. (2002). Measuring Sprawl and Housing Centers of Activity. Smart Growth America: 42.

Hadi, M.A, (2013). Urban Sprawl di Kota Semarang: Karakteristiknya dan Evaluasinya Terhadap Rencana Detail Tata Ruang Kota. Unpublished Thesis, Geography Faculty, Gadjah Mada University, Yogyakarta

Handayani, W., Rudiarto, I. (2014). Dynamics of Urban Growth in Semarang Metropolitan Central Java: An Examination Based on Built-Up Area and Population Change. Journal of Geography and Geology 6(4): 80-87.

Hasse, J., Lathrop, R. G. (2003). A Housing-Unit Level Approach to Characterizing Residential Sprawl. Photogrammetric Engineering and Remote Sensing, 69(9): 1021-30.

Inostroza, Luis, Rolf Baur, and Elmar Csaplovics. (2013). Urban Sprawl and Fragmentation in Latin America: A Dynamic Quanti Fi Cation and Characterization of Spatial Patterns. Journal of Environmental Management 115:

CBS (Central Bureau of Statistics of Semarang). (2017). Kota Semarang Dalam Angka 2017.

Jaya, L.M.G. (2009). Analisis perubahan tutupan lahan di wilayah pesisir teluk kendari menggunakan citra satelit resolusi tinggi (kurun waktu 2003-2009). Forum Geografi, 27(2), 183-192.

Nahib, I.. (2016). Prediksi Spasial Dinamika Areal Terbangun Kota Semarang Dengan Menggunakan Model Regresi Logistik. Majalah Ilmiah Globe, 95-104. 
Pigawati, B., Rudiarto, I. (2011). Penggunaan Citra Satelit Untuk Kajian Perkembangan Kawasan Permukiman Di Kota Semarang. Forum Geografi, 25(2), 140-151.

Pigawati, B., Yuliastuti, N., Mardiansjah, F.H. (2017). Limitations on the Development of The Suburbs Area as The Control. IOP Conference Series: 306-19.

Pozoukidou, G., Ntriankos, I. (2017). Measuring and Assessing Urban Sprawl: A Proposed Indicator System for the City of Thessaloniki, Greece. Remote Sensing Applications. Society and Environment, 8: 30-40.

Prasetyo, A., Koestoer, R.H., Waryono, T. (2016). Pola Spasial Penjalaran Perkotaan Bodetabek : Studi Aplikasi Model Shannon's Entropy. Jurnal Geografi Gea , 16: 144-60.

Rukmana, Nurlaili, S., Rudiarto, I. (2016). Land Use Change in Suburban Area: A Case of Malang City, East Java Province. Geoplanning: Journal of Geomatics and Planning, 3(1): 23-32.

Schneider, A., Woodcock, C.E. (2008). Compact, Dispersed, Fragmented, Extensive? A Comparison of Urban Growth in Twenty-Five Global Cities Using Remotely Sensed Data, Pattern Metrics and Census Information. Urban Studies, 45(3): 659-92.

Shekhar, S. (2004). Urban Sprawl Assessment Entropy Approach. GIS Development, Noida.

Solé-Ollé, A., Rico, M.H. (2010). Does Urban Sprawl Increase The Cost of Providing Local Public Services? Evidence from Spanish Municipalities. Urban Studies, 47(7): 1513-40.

Sudhira, H.S., and T.V. Ramachandra. (2007). Characterising Urban Sprawl From Remote Sensing Data and Using Landscape Metrics. 10th International Conference on Computers in Urban Planning and Urban Management, 1-12.

Suditu, B., Ginavar, A., Muic, A., Iordăchescu, C., Vârdol, A., Ghinea, B. (2010). Urban Sprawl Characteristics and Typologies in Romania. Human Geographies - Journal of Studies and Research in Human Geography, 4(2): 79-87.

Summer, H, Nordman, C. (2008). Accuracy Assessment: Abraham Lincoln Birthplace National Historic Site. Available online: http://www1.usgs.gov/vip/abli/abliaarpt.pdf.

Tian, L., Li, Y., Yan, Y., \& Wang, B. (2017). Land Use Policy Measuring Urban Sprawl and Exploring the Role Planning Plays: A Shanghai Case Study. Land Use Policy, 67: 426-35.

Verma, S., Chatterjee, A., \& Mandal, N. R. (2017). Analysing Urban Sprawl and Shifting of Urban Growth Centre of Bengaluru City, India Using Shannon's Entropy Method. Journal of Settlements and Spatial Planning, 8(2), 89-98. https:/ / doi.org/10.24193/JSSP.2017.2.02

Wilson, E.H., Hurd, J.D., Civco, D.L., Prisloe, M.P, Arnold, C. (2003). Development of a Geospatial Model to Quantify, Describe and Map Urban Growth. Remote Sensing of Environment, 86(3): 275-85.

Wu, K., Zhang, H. (2012). Land Use Dynamics, Built-up Land Expansion Patterns , and Driving Forces Analysis of the Fast-Growing Hangzhou Metropolitan Area , Eastern China ( 1978 e 2008 ). Applied Geography, 34: 137-45. http://dx.doi.org/10.1016/j.apgeog.2011.11.006.

Yeh, A.G., Li, X. (2001). Measurement and Monitoring of Urban Sprawl in a Rapidly Growing Region Using Entropy. Photogrammetric Engineering \& Remote Sensing, 67(1): 83-90.

Yunus, H S. (1999). Struktur Tata Ruang Kota. Pustaka Pelajar. 